\title{
Energy Consumption and Economic Growth Nexus in Mozambique: 1975-2016
}

\author{
Abdul Gafur Nazordine Mahomed Bay* \\ Centre for Research in Health, Science, and Technology of Mozambique, Street 1394, FACIM 322, Maputo, Mozambique \\ *Corresponding author: baygafur@yahoo.com.br
}

\begin{abstract}
This study explores the relationship between energy consumption and economic growth in Mozambique for 1975-2016 period, using Vector error correction model and Granger causality test. The VECM result suggests the existence of unidirectional long-run relationship running from EC to GDP. Granger causality test proposes that energy consumption Granger causes economic growth. Therefore, in Mozambique is indispensable an energy consumption development policy to stimulate economic growth. Mozambique has plentiful energy resources that would boost the development of energy sector and supply the emergent industry without any energy shortage.
\end{abstract}

Keywords: energy consumption, economic growth, VECM, Mozambique

Cite This Article: Abdul Gafur Nazordine Mahomed Bay, "Energy Consumption and Economic Growth Nexus in Mozambique: 1975-2016." American Journal of Energy Research, vol.6, no. 1 (2018): 19-22. doi: 10.12691/ajer-6-1-3.

\section{Introduction}

Literature on the relationship between energy consumption and economic growth recognizes the 1970s oil crisis as the main motivation for research in this area [1]. In fact, the importance of energy for economic growth is indubitable, playing a significant role in countries domestic productivity [2], as evidenced in several studies, most of which done in developed countries, and in a smaller number in Sub-Saharan Africa [3].

Research of energy consumption and economic growth nexus have reported conflicting and non-consensual results, with key effects for energy policy recommendations: (i) energy influence the increase in economic growth, hence conservation policy in this sector is not desirable; (ii) economic growth has impact on energy consumption, thus conservation policy is not any hindrance to economic growth; (iii) economic growth and energy have a feedback influence, an increase in economic growth will lead to a development of the energy sector and vice-versa; (iv) economic growth and energy do not affect each other, any policy implementation in one sector will not effect on another [4].

In the context of Mozambique, [3] addressed a research on the relationship between energy consumption and economic growth for the period of 1980-2011, using autoregressive distributed lag (ARDL) and error correction model (ECM) based Granger causality test, they report a unidirectional causality running from energy consumption to economic growth, which means that economic development is dependent on energy consumption. Therefore, a decline in energy consumption would negatively affect economic growth. Mozambique is gifted with balanced energy resources (hydro, natural gas and coal), and shortly will join the top African energy producers [5]. These assets make this country a good example to explore energy consumption and economic growth nexus. In this sense, this paper aims to contribute to literature examining the relationship between energy consumption and economic growth in Mozambique for the period of 1975-2016. This research is organized as follows: Section 1 describes the energy sector in Mozambique. Section 2 grants a brief literature review. Section 3 specifies data and methodology used to conduct this research. Section 4 exhibits empirical analysis and results. Section 5 presents conclusions of this study and policy implications.

\section{The Energy Sector in Mozambique}

Mozambique has huge amounts of energy resources including hydroelectric potential and coal; natural gas, as well as renewable energy resources. Cahora Bassa dam is one of the 10 largest in the world producing annually 2075 MW of energy; however, only 19\% of its output is destined to Mozambican market, and exporting $80 \%$ to South Africa and Zimbabwe [6]. Other small hydroelectric dams such as Mavúzi, Chicamba, and Corrumana are also generating electricity. Mozambique has potential to build another $5000 \mathrm{MW}$ of hydropower, considering ongoing projects for electricity production [7]. Furthermore, the discovery of about 190 trillion cubic feet of natural gas in Rovuma Basin, north of Mozambique, make it a potential major exporter of Liquefied Natural Gas [8], with production planned to start in 2022 and this natural resource will undoubtedly have an impact on economic growth in the future [9]. Additionally, Mozambique also has huge reserves of mineral coal calculated at 23 billion tons. Moreover, the country has biomass and biofuel 
production potential predictable in 30 million of land [7]. Overall, regardless of increasing production and consumption of conventional energy, Mozambique energy sector is still dominated by traditional biomass (wood, charcoal, and agriculture trash), accounting for $64 \%$ of energy production [ibid]. In Mozambique, the biggest challenge for the energy sector is the expansion of energy production sources (hydro, coal and natural gas), and the inability to develop the use of clean energy. Another challenge is a lack of infrastructure, a common characteristic of low-income countries.Energy sector megaprojects will contribute to Gross Domestic Product (GDP) increased by 7\% in coming years [10]. Figure 1 shows the historical trend of GDP and energy consumption in Mozambique for the period of this study.

\section{Brief Literature Review}

[11] explores the relationship between energy consumption and economic growth in 11 sub-Saharan countries for the period 1980-2003 using Granger test, Vector error correction model (VECM) and ARDL, reports evidence of a bidirectional relationship between energy consumption and economic growth in Gambia, Ghana, and Senegal. However, for Kenya, Nigeria, and Togo there is evidence of a neutral relationship.

[12] surveys energy consumption and economic growth nexus in Tanzania for 1971-2006, employing ARDL and suggest evidence of unidirectional relationship running from energy consumption to economic growth. In another African country [13] discovers similar result for Cameroon during 1971-2009 using ECM. In Tunisia, studies by [14] for a period of 1971-2004 employing VECM, and [1] for 1974-2011 engaging Johansen test, report a bidirectional relationship between energy consumption and economic development.

Studies in non-African countries also suggest non-consensual results: [2] and [15] report a unidirectional causality running from energy consumption to economic growth in China and Greece respectively. On the other hand, [16] and [17] discover a unidirectional causality from GDP to energy consumption in Turkey and USA separately. [18] suggests a bi-directional causality between GDP and total energy consumption in Taiwan. [4] for China, and [19] for the USA did not find any relationship between energy consumption and economic growth. Table 1 provides details of selected literature on energy consumption and economic growth nexus.

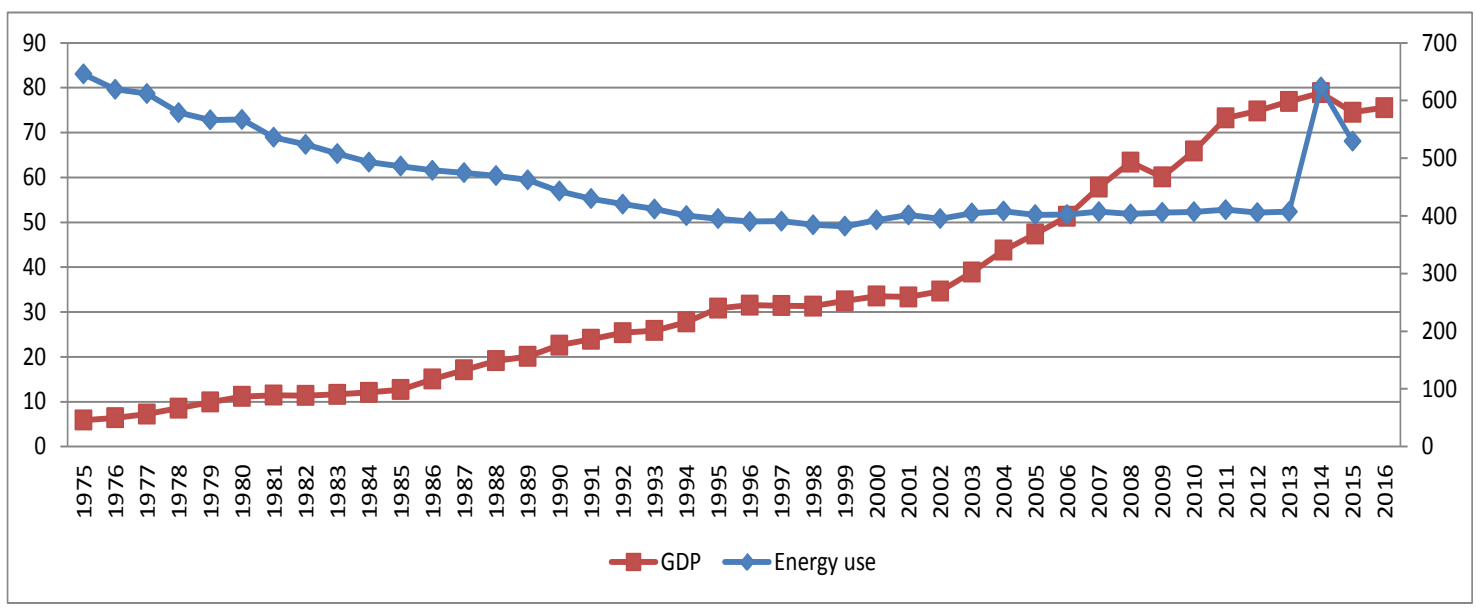

Figure 1. The historical trend of GDP and Energy consumption in Mozambique (Source: World Bank, 2017)

Table 1. Summary of selected empirical studies

\begin{tabular}{|l|c|c|c|c|}
\hline Author (s) & Country & Period & Methodology & Report \\
\hline Nindi\&Odhiambo (2014) & Mozambique & $1980-2011$ & ARDL & GDP EC \\
\hline Saidi\&Hammani (2014) & Tunisia & $1974-2011$ & Johansen test & GDP EC \\
\hline Fondja (2013) & Cameroon & $1971-2009$ & ECM & GDP EC \\
\hline Zhang-Wei \&Xun-Gang (2012) & China & $1990-2009$ & VAR & GDPXEC \\
\hline Yalta \&Cakar (2012) & China & $1971-2007$ & VAR & GDP EC \\
\hline Tsani (2010) & Greece & $1960-2006$ & Toda Yamamoto & GDP EC \\
\hline Odhiambo (2009) & Tanzania & $1971-2006$ & ARDL & GDP EC in the long-run \\
\hline Belloumi (2009) & Tunisia & $1971-2004$ & VECM & Gambia; Ghana $\&$ Senegal GDP $\leftrightarrow$ EC \\
\hline Akinlo (2008) & Kenya; Nigeria \& Togo GDPXEC \\
\hline Lise\& Montfort (2007) & Tub-Saharan countries & $1980-2003$ & \multirow{2}{*}{ GC; VECM; ARDL } & GDP $\rightarrow$ EC \\
\hline Yang (2000) & Turkey & $1970-2003$ & ECM & GDP↔EC \\
\hline Yu \& Hwang (1984) & Taiwan & $1954-1997$ & GC & GNPXEC \\
\hline Kraft \& Kraft (1978) & USA & $1947-1979$ & GC & GNP $\rightarrow$ EC \\
\hline
\end{tabular}

\section{Abbreviation:}

$\mathrm{GDP} \rightarrow \mathrm{EC}$ : indicates a unidirectional causality running from economic growth to energy consumption;

$\mathrm{GDP} \leftarrow \mathrm{EC}$ : indicates a unidirectional causality running from energy consumption to economic growth;

$\mathrm{GDP} \leftrightarrow \mathrm{EC}$ : indicates bidirectional causality;

GDPxEC: indicates no causal relationship;

GC: Granger causality; VECM: Vector error correction method; VAR: Vector autoregressive

ARDL: Autoregressive distributed lag model; TY: Toda and Yamamoto causality test.

Source: Author, 2017. 


\section{Data and Methodology}

This is a bivariate study and time series data consist of GDP per capita measured in billions of dollars and total energy use set in as a proxy for energy consumption (EC). Data is retrieved from World Bank Development Indicator (2017), and it is related to the period of 1975-2016. This research implements Augmented Dickey-Fuller test (ADF) settled by Dickey and Fuller (1979) and Phillips-Perron (PP) technique established by Phillips and Perron (1988), to determine variables order of integration, considering that both are similar but PP is accurate to decrease bias of serial correlation. In addition, this study employs a VECM to estimate the long-run relationship within the Granger causality framework and equations for GDP and EC are as follows:

$$
\begin{aligned}
\Delta G D P_{t} & =\alpha+\sum_{i=1}^{k} \beta_{i} \Delta G D P_{t-1}+\sum_{i=1}^{k} \gamma_{i} \Delta E C_{t-1}+\delta_{\varepsilon t-1}+\mu_{t^{\prime}} \\
\Delta E C_{t} & =\alpha+\sum_{i=1}^{k} \beta_{i} \Delta E C_{t-1}+\sum_{i=1}^{k} \gamma_{i} \Delta G D P_{t-1}+\delta_{\varepsilon t-1}+\mu_{t}(2)
\end{aligned}
$$

$\Delta \mathrm{GDP}$ and $\Delta \mathrm{EC}$ are differences of series; and $\delta_{\varepsilon t-1}$ indicate the correction term resulting from the long-run equilibrium.

\section{Empirical Results}

ADF and PP tests disclose that GDP and EC time series data were non-stationary at a level with corresponding P-values bigger than 5\% allowing acceptance of the null hypotheses. However, after trending without intercept both variables become stationary at first difference and therefore integrated of order I (1), as exhibited in Table 2. Being variables stationary and integrated in the same order, it is time to inspect the presence of long-run equilibrium between GDP and EC, employing Johansen co-integration test, and for that grit, the optimum lag length is selected based on minimum Akaike information criterion of unrestricted VAR estimation. Results displayed in Table 3 report that both Trace and Maximum Eigenvalue tests detect one co-integrating vector at the 5\% critical level, which means that economic growth and energy consumption are co-integrated and they have a long-run relationship. The existence of co-integration suggests the presence of causality; however, these results do not illustrate the path of the relationship.

The result of VECM displays that the coefficient 1 has a negative sign and it is statistically significant, explaining the speed of adjustment towards a long-run relationship from EC to GDP. Consequently, this outcome suggests the existence of unidirectional long-term relationship running from energy consumption to economic growth in Mozambique, supporting the growth hypotheses, as shown in Table 4. This study also investigates Granger causality through pairwise Granger test among variables and results suggest rejection of the null hypothesis on EC does not Granger cause GDP, determining that EC cause GDP (Table 5). This result expresses that a rise in energy consumption leads to an increase in economic growth. Therefore, an energy conservation policy would become a bottleneck for Mozambican economic growth, and it is similar to [3] research findings.

Table 2. Unit Root tests results

\begin{tabular}{|c|c|c|c|c|c|}
\hline \multirow{2}{*}{ Variables } & \multicolumn{2}{|c|}{ ADF } & \multicolumn{2}{|c|}{ PP } & \multirow{2}{*}{ Order of Integration } \\
\cline { 2 - 5 } & Level & $\mathbf{1}^{\text {st }}$ Difference & Level & $\mathbf{1}^{\text {st }}$ Difference & I(1) \\
EDP & 1.07 & -4.86 & 0.84 & -4.87 & I(1) \\
\hline
\end{tabular}

Source: Author, 2017

\begin{tabular}{|c|c|c|c|c|c|c|c|c|c|c|}
\hline & \multicolumn{5}{|c|}{ Trace statistics } & \multicolumn{5}{|c|}{ Maximum Eigenvalue statistics } \\
\hline & Null & Alternative & Statistics & Critical value at $5 \%$ & Prob. & Null & Alternative & Statistics & Critical value at $5 \%$ & Prob. \\
\hline $\mathrm{HCE}^{*}$ & Eq1 & Eq1 & 16.26 & 15.49 & 0.03 & Eq1 & Eq1 & 14.64 & 14.26 & 0.043 \\
\hline HCE & Eq2 & Eq2 & 1.62 & 3.84 & 0.2 & Eq2 & Eq2 & 1.62 & 3.84 & 0.2 \\
\hline
\end{tabular}

Table 3. Results of the cointegration test

Abbreviation: $\mathrm{HCE}=$ Hypothesized number of cointegrating equations

${ }^{*}$ Rejections of the hypothesis at $5 \%$.

Source: Author, 2017

Table 4. Effect of Energy on GDP

\begin{tabular}{lcccc}
\hline & Coefficient & Std. Error & t-Statistic & Prob. \\
\hline C(1) & -0.591407 & 0.236897 & -2.496478 & 0.0179 \\
R-squared & 0.622146 & Mean dependent var & -0.006605 \\
Prob(F-statistic) & 0.000005 & & & \\
F-statistic & 10.53774 & & & \\
Durbin-Watson stat & 2.316823 & & & \\
\hline
\end{tabular}

Source: Author, 2017.
Table 5. Pairwise Granger causality test

\begin{tabular}{lcc}
\hline Null Hypothesis: & F-Statistic & Prob. \\
\hline DGDP does not Granger Cause DEC & 0.05118 & 0.9502 \\
DEC does not Granger Cause DGDP & 3.53882 & 0.0405 \\
\hline
\end{tabular}

Source: Author, 2017.

This study also tests the adequacy of the VECM outcome employing residual diagnosis and it reports uncorrelated series and free of heteroscedasticity effects. 
Stability diagnosis test reveals that the model is stable, as illustrated in Figure 2.

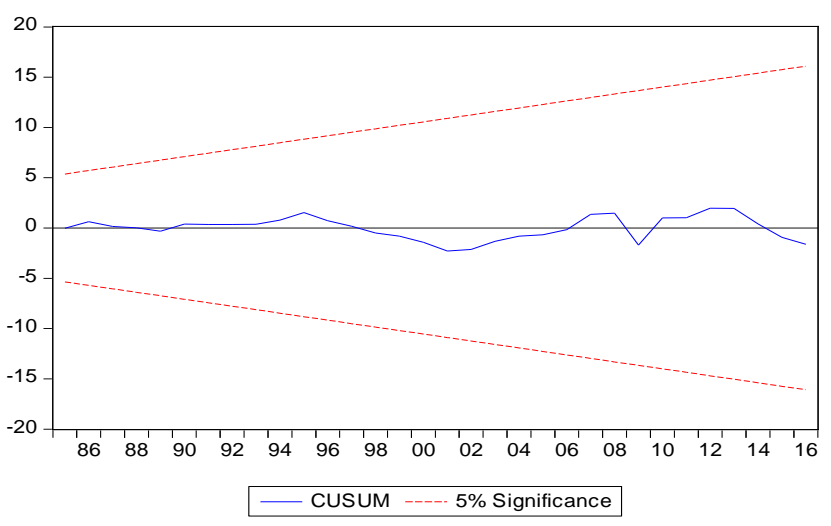

Figure 2. CUSUM test (Source: Author, 2017)

\section{Conclusion and Policy Implications}

This paper investigates energy consumption and economic growth nexus in Mozambique using time series data of the period of 1975-2016, obtained from World Bank (2017). In this study, GDP is dependent variable and energy consumption is an independent variable. This research uses VECM to inspect the long-run relationship between economic growth and energy consumption. It also engages Granger causality test to explore the linkage among series of the study. The VECM result suggests the existence of unidirectional long-run relationship running from EC to GDP. Granger causality test proposes that energy consumption Granger causes economic growth. These results support the growth hypotheses, being indispensable in the implementation of a growth energy policy that would stimulate Mozambican economic growth. Mozambique has plentiful energy resources that would boost the development of the energy sector and supply the emergent industry without any energy shortage.

\section{References}

[1] Saidi, Kais and \& Hammami, Sami, "Energy consumption and economic growth nexus: empirical evidence from Tunisia", American Journal of Energy Research, 2 (4). 81-89. 2014.
[2] Zhang-Wei, Li, and Xun-Gang, Zheng, "Study on Relationship of Energy Consumption and Economic Growth in China", Physics Procedia, 24. 313-319. 2012.

[3] Nindi, Angelique G. and Odhiambo, Nicholas M. "Energy Consumption and Economic Growth in Mozambique: an empirical investigation", Environmental Economics, 5 (4). 83-92. 2014.

[4] Yalta, A, Talha and \&Cakar, Hatice, "Energy consumption and economic growth in China: a reconciliation", Energy Policy, 41, 666-675. February 2012.

[5] IEA Africa Energy Outlook. [Online]. Available: https://www.iea.org/publications/freepublications/publication/WE O2014_AfricaEnergyOutlook.pdf [Accessed Oct. 20, 2017].

[6] Sebitosi, A.B., and da Graça, A., "Cahora Bassa and Tete province (Mozambique): a great potential for an industrial hub in Southern Africa", Energy Policy, 37: 2027-2032. May 2009.

[7] Mahumane, Gilberto and Mulder, Peter, "Mozambique Energy Outlook, 2015-2030: Data, Scenarios and Policy implication", Research Memorandum 2015-7, Faculty of Economics and Business Administration, Vrije Universiteit, Amsterdam. 2015.

[8] Mozambique National Petroleum Institute [Online]. Available: www.inp.gov.mz [Accessed Sep. 10, 2017].

[9] Bay, Abdul Gafur N.M. and Hong, Liang, "Dynamics of the natural gas industry and economic growth in Mozambique", Science Journal of Energy Engineering, 5 (3). 68-77. October 2017.

[10] World Bank. [Online]. Available: http://www.worldbank.org/en/country/mozambique/overview[Acc essed Jul. 10, 2017].

[11] Akinlo, A.E., "Energy consumption and economic growth: Evidence from 11 sub-Sahara African countries", Energy Economics, 30 (5). 2391-2400. September 2008.

[12] Odhiambo, Nicholas, "Energy consumption and economic growth nexus in Tanzania: an ARDL bounds testing approach", Energy Policy 37 (2). 617-622. February 2009.

[13] Wandji, Yris D. Fondja, "Energy consumption and economic growth: evidence from Cameroon", Energy Policy, 61, 1295-1304. October 2013.

[14] Belloumi, Mounir, "Energy consumption and GDP in Tunisia: cointegration and causality analysis", Energy Policy, 37, 27452753. July 2009.

[15] Tsani, Stela Z., "Energy consumption and economic growth: a causality analysis for Greece, Energy Economics", Energy Economics, 32 (3). 582-590. May 2010.

[16] Lise, Wietze and Montfort, Kees, "Energy consumption and GDP in Turkey: is there a co-integration relationship?" Energy Economics 29 (6). 1166-1178. November 2007.

[17] Kraft, J. and Kraft, A., "On the relationship between energy and GNP", Journal of Energy Development 3. 401-403. 1978.

[18] Yang, Hao-Yen, "A note on the causal relationship between energy and GDP in Taiwan", Energy Economics, 22 (3). 309-317. June 2000.

[19] Yu, Eden, S.H., and Hwang, Been-Kwei., "The relationship between energy and GNP: further results", Energy Economics, 6 (3). 186-190. July 1984. 